\title{
OCORRÊNCIA DE ABSCESSO PERIODONTAL EM CAPRINOS DE LEITE
}

\author{
PERIODONTAL ABSCESS OCCURRING IN MILK GOATS
}

\author{
P. L. CAMPELLO ${ }^{1 *}$, S. D. AGOSTINHO ${ }^{1}$, A. C. BORSANELLI ${ }^{1}$, E. GAETTI-JARDIM JR ${ }^{2}$, \\ I. S. DUTRA ${ }^{3}$
}

\section{RESUMO}

O abcesso periodontal é um processo inflamatório purulento circunscrito, que envolve os tecidos que circundam a porção apical do dente. Causado por microrganismos do biofilme bacteriano presente no sulco gengival, geralmente tem como consequência vasta destruição tecidual e reflexos no desempenho animal. As doenças periodontais, e dentre elas os abscessos periodontais, são definidas como enfermidades multifatoriais e polimicrobianas. O desenvolvimento dessas patologias correlaciona-se com diversos fatores que afetam o hospedeiro, como os alimentares, microbiológicos e ambientais. No Brasil, a doença periodontal em ruminantes está associada à praticas de manejo no solo. São escassos os relatos de abscessos periodontais em pequenos ruminantes, embora seja uma enfermidade reconhecida pelos técnicos e produtores rurais como de importância nos sistemas de produção. Inexiste na literatura compulsada relatos sobre a sua ocorrência em caprinos assim como sobre a identificação de microrganismos encontrados nas lesões. Nesse sentido, o objetivo deste trabalho é o de relatar a ocorrência de abscesso periodontal em cabras de leite e identificar os microrganismos. Foram examinados 50 caprinos de rebanho leiteiro de propriedade rural situada no Estado de São Paulo. O material para o diagnóstico microbiológico foi colhido por punção de abscessos não fistulados, cultivado em ágar sangue enriquecido com sulfato ferroso e vitamina $\mathrm{K}$, sob condições de anaerobiose, microaerofilia e aerobiose.

Ao exame clínico foram observadas 3 cabras com presença de nódulos únicos, sem indicação de inflamação de tecidos moles adjacentes na região mandibular, na altura dos dentes molares, que apresentavam bolsa periodontal profunda. Predominaram nos cultivos colônias de Prevotella e Porphyromonas pigmentadas de negro e de bactérias anaeróbias estritas, seguidas de Trueperella pyogenes. O relato da ocorrência de abscesso periodontal é original, assim como o da identificação preliminar dos microrganismos associados a este problema sanitário observado frequentemente em criatórios de caprinos de leite.

PALAVRAS-CHAVE: DOENÇA PERIODONTAL. PERIODONTITE. CAPRINOS. INFECÇÃO PERIODONTAL.

ÁREA TEMÁTICA: Doenças Infecciosas 